\title{
'The Cutting Edge of Cocking About': Top Gear, Automobility and Law
}

Kieran Tranter and Damien Martin ${ }^{*}$

ABSTRACT

This paper argues that the British Broadcasting Corporation's (BBC) television series Top Gear (2002-) presents a significant opportunity to think about automobility, masculinity and law. As a show about cars and car culture it can be seen, and dismissed, as a gratuitous celebration of 'combustion masculinity.' However, its irony, humour and nostalgia combine to highlight that this way of being male lies in the past. Focusing on Top Gear series 13 (June-August 2009) it is argued that the essence of combustion masculinity lies not only in risk and competition but law. However, the show goes further. In its excessive performance of combustion masculinity it engages in gentle critique. In the post-industrial era where the motor vehicle's cultural status is declining Top Gear is itself a vehicle allowing combustion masculinity to be overtaken by less risky, less violent and more lawful ways of being male.

Keywords: automobility, law, Top Gear, masculinity, irony

\section{INTRODUCTION}

Scholarship on 'automobility' has been broad, defining automobility as not just machine-human interactions but the cultural and physical spaces constructed for and by automobiles. ${ }^{2}$ Within this context exploration of automobility has often considered gender. Car culture has obviously been associated with men and masculinity, and has become a significant site for the consideration of

\footnotetext{
1 'The Cutting Edge of Cocking About' was featured on a promotional poster for Top Gear.

* Senior Lecturer, Griffith Law School, Griffith University, Gold Coast campus; Research Assistant, Griffith Law School, Griffith University, Gold Coast campus.

${ }^{2}$ John Urry, 'The 'System' of Automobility' (2004) 21 Theory, Culture and Society 25, 26; Steffen Böhm and others, 'Introduction: Impossibilities of Automobility' in S Böhm and others (eds), Against Automobility (Blackwell, 2006) 4.
} 
culture, technology and gender. ${ }^{3}$ The car also depends on and generates detailed and specific laws; from the rules of the road and design standards, to liability and risk allocation, to policing of car associated criminal activities. But beyond technical socio-legal scholarship concerning the administration of certain laws-whether insurance schemes are adequate ${ }^{4}$, or the effectiveness of mandatory detention for car crimes ${ }^{5}$, or the pitfalls and promises of random alcohol and drug testing of drivers ${ }^{6}$ - the cultural relations between automobility and law have not been as well explored. ${ }^{7}$ This paper contributes to this thinking about automobility and the law; in doing so it takes automobility as a site for consideration of technology, gender and law.

It does this through a cultural legal study of Season 13 (June-August 2009) of BBC2's Top Gear to excavate a specific combination of technology, gender and law-combustion masculinity. Much of the show seems to be a celebration of combustion masculinity. But in its excessive performance combustion masculinity is undone. The show articulates how risk and competition combine to form combustion masculinity. It further reveals the function of law within combustion masculinity; for combustion masculinity is constituted through norms and transgression. However, the show's humour, its ironies and its nostalgia presents this way of being male as past. In linking combustion masculinity with the definitional industrial-consumer icon-the automobile-and through

\footnotetext{
${ }^{3}$ For example see contributors to Tanu Priya Uteng and Tim Cresswell (eds), Gendered Mobilities (Ashgate, 2008); See also Malcolm Vick, 'Danger on the Roads! Masculinity, the Car and Safety' (2003) 22 Youth Studies Australia 32; Georgine Clarsen, '"The Woman Who Does": A Melbourne Motor Garage Proprietor' in L Doan and J Garrity (eds), Sapphic Modernities: Sexuality, Women and National Culture (Palgrave Macmillan, 2006); Andrew Thacker, 'Traffic, Gender, Modernism' in S Böhm and others (eds), Against Automobility (Blackwell, 2006).

${ }^{4}$ See for example J C McRuer, 'The Motor Car and the Law' (1966) 4 Osgoode Hall Law Journal 54; Jeffrey O'Connell and Robert H Joost, 'The Economics and Politics of Choice No-Fault Insurance ' (1986) 72 Virginia Law Review 61.

${ }^{5}$ See for example Paul J Slobodian and Kevin D Browne, 'A Review fo Car Crime in England and Wales' (2001) 31 British Journal of Social Work 465, 471-475; Neil Morgan, 'Capturing Crims or Capturing Votes? The Aim and Effects of Mandatories' (1999) 22 University of New South Wales Law Journal 267.

${ }^{6}$ Jeremy Prichard and others, 'Detouring Civil Liberties? Drug-Driving Laws in Australia' (2010) 19 Griffith Law Review: Law Theory Society 330; Barry Watson and James Freeman, 'Perceptions and Experiences of Random Breath Testing in Queensland and the Self-Reported Deterrent Impact on Drunk Driving' (2007) 8 Traffic Injury Prevention 11; Ross Homel, 'Drink-Driving Law Enforcement and the Legal Blood Alchohol Limit in New South Wales' (1994) 26 Accident Analysis and Prevention 147.

${ }^{7}$ There is some literature considering automobility and law. See for example Sarah S Lochlann Jain, '"Dangerous Instrumentality": The Bystander as Subject in Automobiliy' (2004) 19 Cultural Anthropology 61; Kieran Tranter, 'Mad Max: The Car and Australian Governance' (2003) 5 National Identities 67; Jameson M Wetmore, 'Implementing Restraint: Automobile Safety and the US Debates over Technological and Social Fixes' in J Conley and AT McLaren (eds), Car Troubles: Critical Studies of Automobility and Auto-Mobility (Ashgate, 2009).
} 
highlighting the cultural decline of the car within post-industrial society, the show is, ironically, progressive. Notwithstanding the conservative bluster of its hosts Top Gear is significant for it not only locates law in the formation of combustion masculinity but allows the letting go of combustion masculinity and enables transition to less competitive, more risk sensitive, more lawful masculinities.

\section{TOP GEAR AS COMBUSTION MASCULINITY}

Top Gear seems a strange choice for a cultural legal study. An internationally popular infomercial type show about cars, it is many steps removed from the established law in literature texts of early cultural legal studies. Law is present, and as will be seen is present significantly in Top Gear, but the show is not about lawyers and courtrooms. Absent are the obvious law signifiers. There are no offices, police cells, judicial chambers, gavels, wigs, distressed victims, juries and aggrieved parties that early cultural legal studies analysed. ${ }^{8}$ Instead, there are cars. Usually, expensive, fast and new cars being driven at speed on racetracks or objects of desire surrounded by the mostly male audience in the cavernous set (an aircraft hangar at Dunsfold Aerodrome in Surrey). In this Top Gear can superficially be seen to the car what Sex and the City (1998-2004) was to women's footwear; a celebration of excessive consumption of elite brands and bespoke products. ${ }^{9}$

Top Gear has its origins in 1977 as a 30 minute magazine show featuring road tests of new-to-market models on BBC TV. ${ }^{10}$ This form of the show ebbed and flowed in presenters and popularity until production was halted in 2001. Its current incarnation was launched by BBC2 in 2002 as essentially a new show with new presenters and format. This new model Top Gear has been a phenomenal success in the UK and also worldwide. As at March 2012 there have been 18 seasons amounting to 146 episodes that have been seen by 350 million viewers across 170 countries. Indeed, Frances Bonner

\footnotetext{
${ }^{8}$ Leslie J Moran and others, 'Introduction' in LJ Moran and others (eds), Law's Moving Image (GlassHouse, Press, 2004) xiii.

${ }^{9}$ Angela McRobbie, 'Young Women and Consumer Culture' (2008) 22 Cultural Studies 531, 539-541.

${ }^{10}$ Stephen Harrington, 'Top Gear, Top Journalism: Three Lessons for Political Journalists from the World's Most Popular TV Show' (2010) 24 Continuum: Journal Media \& Cultural Studies 933, 934.
} 
suggests that it is the most watched television show in the world. ${ }^{11}$ The format of each hour long episode is similar; a hybrid of talk-show with live audience and pre-filmed 'magazine' segments. Reoccurring segments are the 'Star in a Reasonably Priced Car' where UK specific celebrities are filmed and timed doing a lap of a racetrack in a budget-level production car, the 'Cool Wall', where the presenters allocate photographs of cars onto a table measuring their highly debatable 'coolness', and challenges. The challenges involve the presenters in a competition. In season 13 the challenges included trying to outrun the Royal Mail in a Porsche Panamera ${ }^{12}$, purchasing and modifying a first car for a 17 year-old (male) on a budget of $£ 2,500^{13}$ and making a television advertisement for a diesel powered VW Scirocco. ${ }^{14}$ Between all this the presenters do reviews and comparisons of cars like the original Top Gear, but unlike the older model, the cars reviewed are usually prestigious, expensive and high performance, and the comparison is humourous without the drab technicality usually associated with motor journalism. ${ }^{15}$ But it is not the cars, nor traditional journalism about cars (road tests, comparisons, discussions of performance, fuel economy, braking distances) that accounts for the success of the show. The stars of the show are not the Mercedes-Benz SL65 AMG Black Series or Jaguar XFR (two of the expensive high performance cars tested in season $13^{16}$ ) but the three presenters; Jeremy Clarkson, Richard Hammond and James May. ${ }^{17}$

Jeremy Clarkson, tall and striking, is the patriarch of the show. Having become a celebrity while a presenter on the original Top Gear during the late-1990s, the current Top Gear was his brainchild and Clarkson paces the set with a 'lord of manor' proprietorial 'I'll say what I damn well like...' ownership. ${ }^{18}$ If Clarkson is the ruling lord then Richard Hammond is the heir-in-waiting. Boyish and short, with the in-show nickname 'Hamster', Hammond shot to Clarkson-challenging fame by surviving a wreck in a rocket powered dragster on 20 September $2006 .{ }^{19}$ Much of the humour of the

\footnotetext{
${ }^{11}$ Frances Bonner, 'Top Gear: Why Does the Word's Most Popular Progreamme Not Deserve Scrutiny' (2010) 5 Critical Studies in Television 32, 32.

${ }^{12}$ Brian Klein Season 13, Episode 4 Top Gear (BBC, Television, 12 July).

${ }^{13}$ Brian Klein Season 13, Episode 3 Top Gear (BBC, Television, 5 July).

${ }^{14}$ Brian Klein Season 13, Episode 7 Top Gear (BBC, Television, 2 August).

${ }^{15}$ Harrington (n 10) 935.

${ }^{16}$ Brian Klein Season 13, Episode 5 Top Gear (BBC, Television, 19 July).

${ }^{17}$ Bonner (n 11) 35.

${ }^{18}$ Ibid, 37.

${ }^{19}$ Brian Klein Season 9, Episode 1 Top Gear (BBC, Television, 28 January).
} 
show comes from the on-screen rivalry and competitive banter between Clarkson and Hammond. ${ }^{20}$ The presence of these two means that the third presenter, James May, tends to be in the background. Coming onto the show in 2003 May plays a straighter persona than Clarkson or Hammond. Dubbed 'Captain Slow', May is often the object of jokes for driving carefully (that is slowly) and understanding the technicalities of car engineering.

All this screen time for three middle-aged, middle-class, white, heterosexual males as they mess about with cars while mouthing-off to a jovial, sharing-the-joke, mostly male audience, presents a fundamental connection. In Top Gear cars and car culture are firmly parked within a particular masculinity. ${ }^{21}$ Sarah S. Lochlann Jain writes that:

Historically, the car was picked up nearly immediately as a tool to renew a masculinity challenged by industrialization...This assertion of masculinity through technology followed ambivalent tracks. On the one hand, the driver's seat reasserted the male as the family head in control of its destiny. The car became a symbol of paternity — daddy driving the family on around on Sunday. On the other hand, the car provided the male with a means of escape from the family and domesticity - it was the private place that gentlemen could drink, swear, and court. ${ }^{22}$

Top Gear manifests this ambivalence. Women are mostly absent. There are few women in the audience, and the ones that are (the reluctant girlfriend dragged along?) seem to be uncomfortably positioned at the front of the crowd around the presenters. ${ }^{23}$ There are even fewer women featured on the show. This absence was clear to the one female guest in season 13, actress Sienna Miller, who in the 'Star in a Reasonably Priced Car' car segment was disappointed at her pace, and apologised to all

\footnotetext{
${ }^{20}$ Bonner (n 11) 36.

${ }^{21}$ Ibid, 40.

${ }^{22}$ Lochlann Jain Sarah S 'Violent Submission' (2005) 61 Cultural Critique 186 at 195.

${ }^{23}$ Bonner (n 11) 42.
} 
women for 'letting [them] down. ${ }^{24}$ The three teenage girls called upon to score the handbrake turns of the presenters in the 'Car for a 17 year-old' segment are decidedly not amused, notwithstanding the presenters' calls that 'handbrake turns turn women on. ${ }^{25}$ While women are not very present they are talked about. In the 'Star in a Reasonably Priced Car' segment in episode 13:6 AC/DC singer Brian Johnston talks about his youthful heterosexual exploits in a Mini Minor ${ }^{26}$ and comedian Michael McIntyre jokes about how he bought his first car as an 'attempt to seduce women' and failed miserably. ${ }^{27}$ The presenters regularly refer to their wives. Clarkson points out his first girlfriend's house with a 'I had sex there, ${ }^{28}$ and is shown using the reversing camera in a Range Rover to spy on women. ${ }^{29}$ Hammond talks of his youthful strategies for picking-up women at nightclubs ('go ugly and go home early') and applies that principle to a car auction. ${ }^{30}$ There is also the feminisation of cars, or at least the feminisation of the preferred supercars. A new Ferrari is described lustfully as 'exquisite' and 'beautiful' ${ }^{31}$ and in the Royal Mail challenge the presenters must win in order to 'defend the honour' of the Porsche. ${ }^{32}$ In this the show, like the car in Lochlann Jain's analysis, is a place for male expressions away from the domestic realm of women, care and responsibility. It is where the 'lads' as they are referred to in the Top Gear promotion media, can be lads. And this screened 'lad-ness' comes through the car.

Sarah Redshaw in In the Company of Cars (2008) terms the phrase 'combustion masculinity' to capture the connections between the sort of masculinity projected by Top Gear and the car. ${ }^{33}$ Redshaw defines combustion masculinity as a violent, invasive drive to subdue machine and world. ${ }^{34}$ She locates combustion masculinity as an extreme manifestation of male sexuality. ${ }^{35}$ It involves alternating of pressure and release, of anticipation of limits and ecstasy of surpassing. In this,

\footnotetext{
${ }^{24}$ Brian Klein Season 13, Episode 5 Top Gear (BBC, Television, 19 July).

${ }^{25}$ Brian Klein Season 13, Episode 2 Top Gear (BBC, Television, 28 June).

${ }^{26}$ Brian Klein Season 13, Episode 6 Top Gear (BBC, Television, 26 July).

${ }^{27}$ Brian Klein Season 13, Episode 3 Top Gear (BBC, Television, 5 July).

${ }^{28}$ Brian Klein Season 13, Episode 1 Top Gear (BBC, Television, 21 June).

${ }^{29}$ Brian Klein Season 13, Episode 6 Top Gear (BBC, Television, 26 July).

${ }^{30}$ Ibid.

${ }^{31}$ Brian Klein Season 13, Episode 7 Top Gear (BBC, Television, 2 August).

${ }^{32}$ Brian Klein Season 13, Episode 4 Top Gear (BBC, Television, 12 July).

${ }^{33}$ Sarah Redshaw, In the Company of Cars: Driving as a Social and Cultural Practice (Ashgate, 2008).

${ }^{34}$ Ibid, 83, 122.

${ }^{35}$ Ibid, 122.
} 
combustion masculinity, notwithstanding its modernist technological expression through motor vehicles, presents as primal. It has an onanistic emphasis on self-fulfilment and self-expression, and if there is audience or gender community towards which combustion masculinity is expressed and received it is other males. It is male identity within male communities that drives Top Gear. Women are clearly on a side street; the main thoroughfare is men communicating, indeed constituting themselves through combustion masculinity. Identity is manufactured and stabilised through engagement with a specific complex, modern technological object and this production and maintenance can be seen to arise through risk and competition. The combustion of combustion masculinity prioritises the technical; it is the energy released in the controlled explosion within an internal combustion engine that defines a motor vehicle. As such the gear in Top Gear is the car. However, it is what the car allows rather than its thing-ness that is emphasised. While there have been many studies that have linked technological activity to men and male social control, ${ }^{36}$ this male knowledge/power is not the feature billing in Top Gear. What is on show repeatedly in Top Gear is a certain type of doing in cars. From the 'Star in a Reasonably Price Car' segment to the worshipping of Formula One superstar Michael Schumacher in 13:1, to the over-the-top stunt driving in 13:3, to a drag race between a McLaren F1 and a Bugatti Veyron in 13:2, it is the ability to drive a car in an excessive and specular fashion that is valued. 'Use more speed' Clarkson announces as the best solution to any automotive difficulty; while being overtaken is a 'sign of weakness. ${ }^{37}$ Hammond, all sparkling eyes and toothy grin whoopees like a schoolboy as he burns rubber and slides around corners in the supercharged V8 Vauxhall VXR8 Bathurst Edition. ${ }^{38}$ Male identity and pride is seen as stemming from the mastery of car. This speed-limit-skill nexus is what Redshaw and other researchers have repeatedly identified as the operative element of combustion masculinity. ${ }^{39}$ Combustion

\footnotetext{
${ }^{36}$ See for example Cynthia Cockburn, Brothers: Male Dominance and Technological Change (Pluto Press, 1983).

${ }^{37}$ Brian Klein Season 13, Episode 5 Top Gear (BBC, Television, 19 July).

${ }^{38}$ Brian Klein Season 13, Episode 7 Top Gear (BBC, Television, 2 August).

${ }^{39}$ Redshaw (n 33) 80-95; Linley Walker, 'Under the Bonnet: Car Culture, Technological Dominance and Young Men of the Working Class' (1998) 3 Journal of Interdisciplinary Gender Studies 23; Linley Walker, 'Hydraulic Sexuality and Hegemonic Masculinity: Young Working-Class Men and Car Culture' in R White (ed) Australian Youth Subcultures: On the Margins and in the Mainstream (Australian Youth Clearing House, 1999); Linley Walker, Dianne Butland and Robert W Connell, 'Boys on the Road: Masculinities, Car Culture, and Road Safety Education' (2000) 8 Journal of Men's Studies 153; Linley Walker, 'Car Culture, Technological Dominance and Young Men of the Working Class' in S Tomsen and M Donaldson (eds), Male Trouble: Looking at Australian
} 
masculinity revolves around the hard driving of cars; of the skills of car control at its mechanical limit. It is not the skills of car maintenance, engineering or modification that is on show in Top Gear. The presenters all do pathetically at repairing their cars in the 'Car for a 17 year-old' competition. ${ }^{40}$ Hammond has trouble starting the 1949 Vincent Black Shadow motorcycle and cannot do roadside repairs to its blocked carburettor. ${ }^{41}$ Clarkson is overjoyed when he is able to do the simple and menial task of changing a light bulb in an aging Porsche $944 .{ }^{42}$ The careful and technical skills of car maintenance are seen as distinct from the essence of combustion masculinity in car use and abuse. Cars feminised or not, are not to be loved and cared for. They are to be driven hard and destroyed. Season 13 is full of destroyed cars. The cars from the challenge in Episodes 13:2 and 13:5 are left ruined. ${ }^{43}$ A piano falls on a Morris Marina ${ }^{44}$ and a Mitsubishi Lancer Evolution VII RS is destroyed by machine gun fire from military vehicles. ${ }^{45}$

This positions combustion masculinity as identity away from cars as such. Cars are not so much technical objects that can be comprehended and modified through rational processes of learning and problem solving rather the car facilitates a primal site of expression for male identity. Much discussion in Top Gear season 13 concerns the projections of self that cars perform. It has been well identified that the consumer-citizens of the West communicate status, gender, wealth, profession and age through the vehicles that they drive. ${ }^{46}$ This identity communication through cars is routinely performed by Top Gear. Clarkson's 940 Volvo estate wagon in the 'Car for a 17 year-old' segment is ridiculed as boring and conservative, the 'geography teacher's car. ${ }^{47}$ Jaguars are affirmed as caddish; it is suggested owners of 'Jaaggggs' can flirt with a waitress in front of their wives, run over dogs

Masculinities (Pluto Press, 2003); Dag Balkmar and Tanja Joelsson, 'Feeling the Speed - The Social and Emotional Investments in Dangerous Road Practices' in M Jansdotter Samuelsson, C Krekula and M Åberg (eds), Gender and Change: Power, Politics and Everyday Practices (Karlstad University Press 2012).

${ }^{40}$ Brian Klein Season 13, Episode 2 Top Gear (BBC, Television, 28 June).

${ }^{41}$ Ibid.

${ }^{42}$ Brian Klein Season 13, Episode 5 Top Gear (BBC, Television, 19 July).

${ }^{43}$ Brian Klein Season 13, Episode 2 Top Gear (BBC, Television, 28 June); Klein Season 13, Episode 5 Top Gear (BBC, Television, 19 July).

${ }^{44}$ Brian Klein Season 13, Episode 5 Top Gear (BBC, Television, 19 July).

${ }^{45}$ Brian Klein Season 13, Episode 4 Top Gear (BBC, Television, 12 July).

${ }^{46}$ Rod Giblett, 'Magician's Bower: The Car as Communication Technology' (2000) 27 Australian Journal of Communication 15; Greg Noble and Rebecca Baldwin, 'Sly Chicks and Troublemakers: Car Stickers, Nonsense and the Allure of Strangeness' (2001) 11 Social Semiotics 75; David Gartman, 'Three Ages of the Automobile: The Cultural Logics of the Car' (2004) 21 Theory, Culture and Society 169, 189.

${ }^{47}$ Klein Season 13, Episode 2 Top Gear (BBC, Television, 28 June). 
without consequences and commit white-collar crime. ${ }^{48}$ The phenomena in America and Australia of tribe-like loyalty and violent confrontation between General Motors and Ford owners are discussed. ${ }^{49}$ Car as communication and also the hard driving of cars combine in the Cool Wall segment. Notwithstanding, the for-laughs bickering between Clarkson and Hammond that closed the Cool Wall segment in Season $13,{ }^{50}$ the criterion that separates 'Seriously Uncool' and 'Sub Zero' are speed and handling along with the stylised projection of speed and handling. Sub Zero cars not only go fast; they look like they can go fast. Exotic supercars or expensively tuned production cars populate the 'sub zero' section, while economical hatchbacks and safe family cars are demarcated 'seriously uncool.'

What this comes to is the centrality of risk for combustion masculinity. Risk, particularly the taking of risk, has often been identified with masculinity. ${ }^{51}$ What combustion masculinity emphasises is the performative aspect of this risk-taking. Risk-taking needs to be public. It needs to be seen. According to Jonathan R. Weaver and his colleagues in a recent study of the violence and masculinity, 'manhood'-which is 'public proof ${ }^{52}$ of masculinity identity—is an 'achieved status. ${ }^{, 53}$ It can be 'lost or taken away' at any point, and it may need to be 'reaffirmed when publicly challenged or called into question. ${ }^{54}$ To successfully restore manhood, any actions taken must be public and visible, and must involve an element of risk-taking and 'fearlessness ${ }^{55}$ The car a male is seen in (uncool, cool, subzero), and more significantly the car he is seen taking risks in, is what combustion masculinity is about. While the adrenalin rush and climax of risk-taking - the fear mid-corner that the car is about to roll-manifests the primal sexuality of combustion masculinity, it is the visual of being seen that completes the identity. 'Did you see that!' exclaim the presenters whenever there is specular car based

\footnotetext{
${ }^{48}$ Brian Klein Season 13, Episode 5 Top Gear (BBC, Television, 19 July).

${ }^{49}$ Brian Klein Season 13, Episode 2 Top Gear (BBC, Television, 28 June).

${ }^{50}$ Brian Klein Season 13, Episode 7 Top Gear (BBC, Television, 2 August).

${ }^{51}$ Raymond F Soames, 'Risk Taking on the Roads: An Explanation in Terms of Extinction of Fear, Generalisation, and Overconfidence' (1988) 5 Advances in Behavioural Medicine 193; Karolina Sylwester and Boguslaw Pawlowski, 'Daring to be Darling: Attractiveness of Risk Takers as Partners in Long- and Short-Term Sexual Relationships' (2011) 64 Sex Roles 695.

52 Jonathan R Weaver and others, 'The Proof is in the Punch: Gender Differences in Perceptions of Action and Aggression as Components of Manhood' (2010) 62 Sex Roles 241, 242.

${ }^{53}$ Ibid, 241.

54 Ibid.

55 Ibid, 242-243.
} 
risk-taking. Combustion masculinity is about taking risks in cars and being seen in this risk-taking by other males.

This public affirmation of manhood through observed risk-taking in cars by other men goes hand-onsteering wheel with competition. Competition is the measure of skill and risk-taking. Winning a competition sends a message of superiority to competitors and observers. As such, competition is continually manifested in Top Gear. The challenges are ultimately competitions; whether the Royal Mail verses a Porsche, or whether the challenges between the presenters to pick the best car for a 17 year-old, find the best rear-wheel drive car for under $£ 1,500$ or compete in a classic car regularity rally. The emphasis is on finding a winner. This competitive context also underpins the Star in a Reasonably Price Car segment where the lap times between guests are compared and a 'leader board' of fastest to slowest kept. It is also in the general car review segments where a similar leader board of lap times are kept; and much celebration accompanied the revelation in episode13:1 that the Ferrari FXX had recorded the fastest lap.

What can be seen is that combustion masculinity has its origins as a primal sexual projection, but Top Gear in its visual destruction of cars and its competitions emphasises that the full expression of combustion masculinity is in risk-taking through cars while being seen by other males. Indeed, the point of the television show Top Gear, and its success at attracting and maintaining an international audience, is precisely because it broadcasts images of risk-taking in cars, competition with cars and the visceral excitement of destroying cars. In this it can be seen as a gratuitous celebration of combustion masculinity. Indeed, a cultural legal study of Top Gear is hardly needed to discover this about males and cars. The social scientific studies on combustion masculinity have studied and dissected the masculinity of car culture along these lines. ${ }^{56}$ However, in its excessive enthusiasm for cocking about in cars, the show highlights a thematic to combustion masculinity that has not been identified; the essential place of law for the performance of combustion masculinity.

\footnotetext{
${ }^{56}$ Redshaw (n 33), 80-126; Walker 'Hydraulic Sexuality' (n 39); Walker, Butland and Connell (n 39).
} 


\section{THE LEGALITY OF COMBUSTION MASCULINITY}

The Ferrari FXX had only a brief stay on the leader board in Season 13 of Top Gear. In the very next episode (13:2) Clarkson removes it from pole position. His justification is that the Ferrari completed its lap with non-street legal racing tyres and as such is disqualified. ${ }^{57}$ This is law talk. It is talk of rules, transgression of rules and penalties for transgression. A hitherto unexpressed dictate is exposed that vehicles eligible for the lap time leader board must be in road-ready conditions without modifications and the Ferrari's lap time tag is taken down. Clarkson's actions met little complaint from co-presenters or audience. His judgement and enforcement, his authority to do so and the legitimacy of the rule and the justice of the penalty seems, adopting another Englishman's term, to be 'accepted. ${ }^{58}$ This surfacing of the legal in the Top Gear text is significant. What is glimpsed in this momentary lapse to the juridical is the necessary legality within combustion masculinity.

Of course competitions, games, involve rules and it has been an established move in modern jurisprudence to treat games with rules as proto-legal systems through which the essence or concept of legality could be glimpsed. ${ }^{59}$ That Clarkson plays umpire regarding the Top Gear lap board is possibly insignificant, except it reveals Top Gear as law-full; as full of law. The rules of the competitions are consistently represented. From the authority of the 'man in the white ${ }^{60}$ who passes on the producers' enveloped instructions during the challenges, to the complex discussion of the rules of the time-trial rally in 13:6, to discussion of road policing and law enforcement, law is a continual theme in Top Gear. The 'Car for a 17 year-old' segment spurs the presenters to remember their youthful driver's licence tests. ${ }^{61}$ An annoyed policeman tells the presenters to move their anti-GFC protest in cheap cars on and they do so. ${ }^{62}$ The rear-wing of the Mercedes-Benz SL65 AMG Black Series that extends at over $75 \mathrm{mph}(120 \mathrm{~km} / \mathrm{h})$ is criticised as it alerts the police that the driver is speeding. ${ }^{63}$ The extensive MOT failures of Hammond's 1953 Lanchester LJ 200 purchased for the challenge in 13:6 is shown at

\footnotetext{
${ }^{57}$ Brian Klein Season 13, Episode 2 Top Gear (BBC, Television, 28 June).

${ }^{58}$ HLA Hart, The Concept of Law (Clarendon Press, 2nd edn 1994) 115.

${ }^{59}$ Ronald Dworkin, Taking Rights Seriously (Harvard University Press ,1977) 101-105.

${ }^{60}$ David Fraser, "The Man in White is Always Right:" Cricket and the Law (The Institute of Criminology Monograph Series No 4 1993).

${ }^{61}$ Brian Klein Season 13, Episode 2 Top Gear (BBC, Television, 28 June).

${ }^{62}$ Brian Klein Season 13, Episode 3 Top Gear (BBC, Television, 5 July).

${ }^{63}$ Ibid.
} 
length. Clarkson explains that the Mitsubishi Lancer Evolution VII that was executed by firing squad belonged to a convicted drug runner and that Top Gear was enforcing part of the sentence to have the car destroyed. ${ }^{64}$ This talk, and participation in legality, constitutes a narrative of lawfulness that runs through the series; of rules being applied and participation in juridical processes.

However, this lawfulness is counterpoised by a sustained lawlessness. It is here at the nexus between lawful and lawlessness that the legality of combustion masculinity becomes transparent. In the opening episode of season 13, the presenters announce that 'they looked at all the things they were not supposed to do, but did them anyway. ${ }^{65}$ This anti-establishment ethos runs through the show. Clarkson has built a career on ridiculing the "nanny state ${ }^{66}$ and season 13 has him true to form ridiculing the UK government's response to recent heatwaves ${ }^{67}$ and combatively responding to his critics from the liberal media. ${ }^{68}$ Top Gear's sympathies are with the freedom-loving, risk-taking male and not the institutions of the state or the establishment's preferred organs of public opinion. Clarkson loses the challenge in 13:6 by instigating a race with Ford Mustang when he should have followed the rules and driven smoothly. Instead, the images are of Clarkson in his 1969 Austin-Healy Sprite skidding and rolling around corners 'dogfighting' with the Ford. ${ }^{69}$ The news report that a driver in California had been caught driving at $210 \mathrm{mph}(338 \mathrm{~km} / \mathrm{h})$ in a $65 \mathrm{mph}(105 \mathrm{~km} / \mathrm{h})$ zone and only slapped with a $\$ 500$ fine was greeted by the presenters enthusiastically. First, the speed of the fined driver clearly impressed. Second, the seemingly low (compared with how the UK authorities would have responded) penalty was seen as a reason to move to California where it is 'civilised'. ${ }^{70}$

The suggestion is that for combustion masculinity risk is only risky — it is only worth looking at where there is transgression of a norm. For combustion masculinity it matters not that the norm is a law properly so called relating to speed or driver conduct or a law not so properly called-

\footnotetext{
${ }^{64}$ Brian Klein Season 13, Episode 4 Top Gear (BBC, Television, 12 July).

${ }^{65}$ Brian Klein Season 13, Episode 1 Top Gear (BBC, Television, 21 June).

${ }^{66}$ Barkham Patrick 'How Top Gear Conquered the World' The Daily Mail www.dailymail.co.uk/tvshowbiz/article-1228422/How-Top-Gear-conquered-world-humour-dedicationdetermination.html accessed 4 September 2012.

${ }^{67}$ Brian Klein Season 13, Episode 3 Top Gear (BBC, Television, 5 July).

${ }^{68}$ Brian Klein Season 13, Episode 2 Top Gear (BBC, Television, 28 June).

${ }^{69}$ Brian Klein Season 13, Episode 6 Top Gear (BBC, Television, 26 July).

${ }^{70}$ Brian Klein Season 13, Episode 5 Top Gear (BBC, Television, 19 July).
} 
conventions of responsible and considerate driving; or social expectations of environmentally sensitive behaviour - or laws of nature relating to thermodynamics. What matters is transgression. This transgressive dimension of combustion masculinity — to test to breaking point self and machine, to speed, to drive aggressively and to indulge in other car-based antics-positions the self, indeed locates an ego-ideal, as a desirable state of rebellion or outlaw-ness. It is this norm-transgressiondesire logic (possibly testosterone fuelled illogic) of combustion masculinity that renders it legal. Law is the measure of combustion masculinity. An outlaw is a figure of law as much as the usual lawful figures of judge, policeman and good citizen. ${ }^{71}$ The outlaw is constituted by law, by their actions or by some feature of their being that makes them illegal, forbidden or criminal. ${ }^{72}$ The laws of drink and dangerous driving, the infrastructure of enforcement, the highway patrol cars and speed cameras, laws of civil liability, norms of safe, considerate driving, the technical standards of vehicle design and engineering and the physics of Newtonian forces, form the dotted white line through which combustion masculinity is constituted on the other side.

Law is there at the moment of ignition of combustion masculinity. The all significant risk-taking is a legal act. Its enjoyment and its masculinity affirming visual spectacle arises from norm transgression. Top Gear is therefore legal not because of the images of law enforcement-Clarkson applying the rules to the leader board, the annoyed policeman or the judicially endorsed destruction of the Mitsubishi—but because risk to be risky needs a norm to be measured against. Risk is only risk if there is transgression, or at least attempted transgression. If the essence of combustion masculinity is risk-taking, then Top Gear's lawfulness-lawlessness tension reveals that the essence of risk is law. This is ironic, that the outlawed risk-taking through cars of combustion masculinity is profoundly, necessarily legal. It is this identification of an ironic registry within Top Gear that opens to its gentle critique of combustion masculinity.

\footnotetext{
${ }^{71}$ Elizabeth V Spelman and Martha Minow, 'Outlaw Women: An Essay on Thelma \& Louise' (1992) 26 New England Law Review 1281, 1285.

${ }^{72}$ Louise Harmon, 'Bob Dylan on Lenny Bruce: More an Outlaw than you ever were' (2011) 38 Fordham Urban Law Review 1287, 1295.
} 


\section{COCKING ABOUT WITH COMBUSTION MASCULINITY}

Top Gear's male audience is clearly attracted by the spectacular risk-taking of combustion masculinity on show. It is also attracted to its humour. The presenters, in their pre-filmed segments and in their in-studio chatting, play for laughs. Word-play and sight gags abound. The show is as much a comedy as it is a car show. ${ }^{73}$ Its comedic nature is often affirmed by the UK regulator of television content, Ofcom that has ruled that offensive or race specific comments made by the presenters are not in breach of broadcasting codes given the humourist context of the show. ${ }^{74}$

One of the regular sites for humour is homoerotic references and banter. ${ }^{75}$ The teenage girls called upon to judge the presenters' handbrake turns are bored, disinterested and score the presenters zero. However, the male audience seems much more enthusiastic. There is something queer going on. Clarkson spends a lot of time in the interview with Stephen Fry particularly interested in a gay cruising app on Fry's smartphone ${ }^{76}$ Hammond in the race of 1949 segment 'straddling his boyhood hero' quizzically keeps commenting that he is 'coming up behind James May'. ${ }^{77}$ For Lochlann Jain this queer incursion within combustion masculinity is to be expected. The male focus, the absence of women, the hard aggression, the impressing other males through risky car exploits via the pretence of impressing women, strongly codes combustion masculinity as homosexual rather than heterosexual. ${ }^{78}$ The 'high' culture of the automobility reflects this: J G Ballard's Crash (1973) climaxes with homosexual intercourse between Ballard and Vaughan ${ }^{79}$; Jack Kerouac's On the Road (1957) is a love letter from Kerouca to his real life travelling partner-in-minor crime Neal Cassady, ${ }^{80}$ and, beyond the cut and abused cars in George Miller's Mad Max trilogy $(1979,1981,1985)$ there is an over-emphasis on injuries to Mel Gibson's leather-clad body. ${ }^{81}$ So while on the surface Top Gear's homoerotic

\footnotetext{
${ }^{73}$ Harrington (n 10) 938-940.

74 'Top 10 Jeremy Clarkson Gaffes' The Telegraph www.telegraph.co.uk/news/celebritynews/9010164/Top-10Jeremy-Clarkson-gaffes.html accessed 4 September 2012.

${ }^{75}$ Bonner (n 11) 41.

${ }^{76}$ Brian Klein Season 13, Episode 2 Top Gear (BBC, Television, 28 June).

${ }^{77}$ Brian Klein Season 13, Episode 1 Top Gear (BBC, Television, 21 June).

${ }^{78}$ Lochlann Jain (n 22) 197-198.

${ }^{79}$ JG Ballard, Crash (Vintage 1973), 202; See Barbara Creed, 'The Crash Debate: Anal Wounds, Metalic Kisses' (1998) 39 Screen 175, 178-179.

${ }^{80}$ Jack Kerouac, On the Road (Penguin, 1957); See Dan Napelee, 'On the Road: THE ORIGINAL SCROLL; Or, We're Not Queer, We're Just Beats' (2011) 69 The Explicator 72.

${ }^{81}$ George Miller Mad Max (Village Roadshow Pictures, Film, 12 April); George Miller Mad Max 2: The Road Warrior (Warner Bros, Film, 24 December); George Miller and George Oglivie Mad Max: Beyond
} 
banter is part of its established comedic material, it reflects the queer undercurrent that cuts the heterosexuality of combustion masculinity.

What can be seen is a double irony within Top Gear. The first relating to combustion masculinity's necessary relations with law; the second is its highlighting combustion masculinity's unstable heterosexual credentials. These ironies point to a substantial alternative message travelling within the Top Gear mega-text. It can be seen as a celebration of combustion masculinity and the show has its detractors in the liberal media, from women's groups and from victims of motor vehicle accidents that see it solely as such. But these critics do not see the irony also at play in the show and as such miss that it is not so much a celebration of combustion masculinity but a gentle critique.

The show has a profound sense of the past. Notwithstanding, the racetrack laps of new cars, nostalgia is never very far from the surface. Even more than talking about women, the presenters talk of their past. Often this is combined, as can be seen Clarkson's, Hammond's and the guests' sharing the memory of their youthful sexual exploits. Hammond's relationship with the Vincent Black Shadow motorcycle, the remembering of driving tests, the joy of Clarkson and Hammond at the car rally in 13:6 that there were so many cars that they had dreamed of owning, all reference the past. Indeed, repeatedly the challenges go back in time. The 'Race of 1949' challenge in 13:1 with Clarkson shovelling coal in a 1949 steam train, May in a 1949 Jaguar XK120 and Hammond on the 1949 Vincent motorcycle is the most obvious ${ }^{82}$; but the rear-wheel-drive competition in 13:5 also looks back to an earlier period of automotive design when rear-wheel-drive vehicles were de jure rather than the contemporary standard of front-wheel-drive. ${ }^{83}$ The 'Car for the 17 year-old' challenge is a vehicle for the presenters to remember and relive their real or imagined first years on the road. ${ }^{84}$ This nostalgia is evident in the final segment of the final episode of season 13. Clarkson does a review of an Aston Martin Vantage with a new V12 engine. The travel documentary quality footage has the

Thunderdome (Warner Bros, Film, 10 July); See Christopher Sharrett, 'Myth, Male Fantasy and Simulacra in Mad Max and The Road Warrior: The Hero as Pastiche' (1985) 13 Journal of Popular Film and Television 80, 84.

${ }^{82}$ Brian Klein Season 13, Episode 1 Top Gear (BBC, Television, 21 June).

${ }^{83}$ Brian Klein Season 13, Episode 5 Top Gear (BBC, Television, 19 July).

${ }^{84}$ Brian Klein Season 13, Episode 2 Top Gear (BBC, Television, 28 June). 
Aston Martin blasting through empty, twisty rural roads. Clarkson is melancholy. He is lamenting that this excessive piece of automotive consumption has come to the end of its run:

What it makes me feel, though, is sad. I just can't help thinking that thanks to all sorts of things, the environment, the economy, problems in the Middle East, the relentless war on speed - cars like this will soon be consigned to the history books [pause] just have this horrible, dreadful feeling that what I am driving here is an ending. ${ }^{85}$

What Clarkson acknowledges is that a decade into the twenty-first century, the car is in decline.

The car is the iconic technological object of the twentieth century. ${ }^{86}$ Automobility has come to define space and time, especially in the West. ${ }^{87}$ Western landscapes, western lifestyles expectations of how to live and how to move about has been defined by an expectations of human-car cybernetic relations. ${ }^{88}$ The car was the epitome of industrial capitalism. It gave it the name Fordism. ${ }^{89}$ In this, combustion masculinity with its risk-taking can be seen as the necessary way of being male to work the big and dangerous machines of the Fordist assembly line and fight its mechanised industrial wars. ${ }^{90}$ Notwithstanding, the fabulous alternative histories of the motor vehicle by Georgina Clarsen that argue that during the pioneer period of motoring women were conspicuously present as owners, racers and mechanics, ${ }^{91}$ by the mid-twentieth century the car was consumed by men as Lochlann Jain observed, as patriarch or as freedom from women and care. ${ }^{92}$ It was also made for men by men

\footnotetext{
${ }^{85}$ Brian Klein Season 13, Episode 7 Top Gear (BBC, Television, 2 August).

${ }^{86}$ Peter Freund and George Martin, 'The Social and Material Culture of Hyperautomobility: "Hyperauto"' (2009) 29 Bulletin of Science, Technology and Society 476.

${ }^{87}$ Cotten Seiler, Republic of Drivers: A Cultural History of Automobility in America (Chicago University Press, 2008), 144-145; Peter Merriman, 'Automobility and the Geographies of the Car' (2009) 3 Geography Compass 586; Peter Merriman, 'Marc Augé, Non-Places, and the Geographies of England's M1 Motorway' (2004) 21 Theory, Culture and Society 145.

${ }^{88}$ Deborah Lupton, 'Monsters in Metal Cocoons: 'Road Rage' and Cyborg Bodies' (1999) 5 Body and Society 57 , 59-65; Urry (n 2) 26-31; Tranter (n 7) 77-78.

${ }^{89}$ Gartman (n 46) 177.

${ }^{90}$ Raewyn Connell, Masculinities (Allen and Unwin, 2nd edn 2005), 193.

${ }^{91}$ Georgine Clarsen, Eat my Dust: Early Women Motorists (John Hopkins University Press 2008).

${ }^{92}$ Lochlann Jain (n 22) 195.
} 
employed by Ford at Detroit, by British Motor Corporation at Longbridge, by Volkswagen at Wolfsburg and by General Motors Holden at Fishermans Bend, Melbourne.

However, the car's cultural status has changed. ${ }^{93}$ The centres of design and manufacturing have moved East and the consumers of cars have changed. Women buy and drive cars; indeed suburban women with children can be seen as doing more miles in cars then the male breadwinner just driving to and from work. ${ }^{94}$ The roads are no longer the preserve of the male 'road warriors' impressing each other with their cars and their risk-taking. The roads have been tamed by freeway construction, speed cameras and random breath-testing. The modern period when town planning gave preference to the needs of motorists has become challenged as the interests of non-motorists have become more privileged. ${ }^{95}$ Cars have been tamed by safety improvements and electronic interventions; they have become semi-intelligent beings that can take control from a wayward driver to prevent the rubber smoking signatures of combustion masculinity. ${ }^{96}$ These new cars sense a pending accident and apply brakes, they can match their speed to a vehicle ahead and some can park themselves. In this law can be seen to have had a profound impact on the use and evolution of the motor vehicle over the twentieth century. One of the present authors identified the motor vehicle during the pioneer period of motoring as giving rise to modernist governing legalities of licencing, registries and policing. ${ }^{97}$ From this foundational legalism, law has over the decades legislated safety standards, liability allocations, road design, pollution and economy improvements. ${ }^{98}$ Modern law's war on risk has been a significant factor in the domestication of the car.

\footnotetext{
93 Cotten Seiler, 'The Ends of Automobility' (2010) 26 History and Technology 389.

${ }^{94}$ Sarah S Lochlann Jain, 'Urban Errands: The Meaning of Mobility' (2002) 2 Journal of Consumer Culture 385.

${ }^{95}$ Bill Luckin and David Sheen, 'Defining Early Modern Automobility' (2009) 6 Cultural and Social History

211; Chris Butler, 'Slicing Through Space: Mobility, Rhythm and the Abstraction of Modernist Transport Planning' (2008) 17 Griffith Law Review: A Journal of Social and Critical Legal Studies 470.

${ }^{96}$ Kingsley Dennis and John Urry, 'Post-Car Mobilities' in J Conley and AT McLaren (eds), Car Troubles: Critical Studies of Automobility and Auto-Mobility (Ashgate, 2009), 245-246.

${ }^{97}$ Kieran Tranter, "The History of the Haste-Wagons': The Motor Car Act 1909 (Vic), Emergent Technology and the Call for Law' (2005) 29 Melbourne University Law Review 843. See also John William Knott, 'Speed, Modernity and the Motor Car: The Making of the 1909 Motor Traffic Act in New South Wales' (1994) 26 Australian Historical Studies 221; William Plowden, The Motor Car and Politics in Britain 1896-1970 (Penguin Books, 1973); James J Flink, The Automobile Age (MIT Press, 1988).

${ }^{98}$ Sarah S Lochlann Jain, Injury: The Politics of Product Design and Safety Law in the United States (Princeton University Press, 2006); Lochlann Jain (n 94); John William Knott, 'Road Traffic Accidents in New South Wales, 1881-1991' (1994) 34 Australian Economic History Review 80; JR Spencer, 'Motor-Cars and the Rule in
} 
With this domestication the raw skills of mechanical mastery of manual gearboxes, unassisted steering, temperamental brakes and ponderous suspension have been negated by hydro-electronic argumentation. Even car aesthetics have changed. The chrome and fins, the aggressive grills, the sculptural expressions of power and speed have been replaced by different, potentially female values of economy, packaging and ease of use. The driver of these changes has been the legislating of economy and safety standards. It has also been the changing consumers of cars. Motor vehicles were always marketed as the consumer good par excellence $e^{99}$ and with the documented equalising of genders of car drivers and owners ${ }^{100}$ it can be seen that the feminisation of cars was also being driven by market demand. The outcome of these changes is that cars have become safe. ${ }^{101}$ Through law and the market cars have morphed from a highly invested site of male identity to a user friendly consumer good used by the variously gendered cyborg citizens of the West in their complex negotiations of twenty-first century life. Top Gear's nostalgia for past cars reaffirms that contemporary cars are, mostly, risk free.

This minimisation of risk as a hallmark of the transition from industrial to post-industrial modes of production has been well observed ${ }^{102}$ and the impact of post-industrial 'risk society' on established expressions of masculinity has also been well-explored. ${ }^{103}$ Clarkson's ranting against the nanny state and his requiem for the supercar can be seen as a rear-guard reaction, of a way of being male that is out of time. Clarkson concludes the Aston Martin review and season 13 with a slightly bitter 'good night' accompanied by the image of a car dashing towards the horizon. ${ }^{104}$ For combustion masculinity is out of time. Top Gear expressly acknowledged this in the 'Cheap and Cheerful' challenge in 13:3 ${ }^{105}$

Rylands v Fletcher: A Chapter of Accidents in the History of Law and Motoring' (1983) 42 Cambridge Law Journal 65; Michael John Law, 'Speed and Blood on the Bypass: The New Automobilities of Inter-War London' (2012) 39 Urban History 490, 408-9.

${ }_{99}$ Catherine Gudis, 'Driving Consumption' (2010) 26 History and Technology 369, 371.

${ }^{100}$ Margaret Walsh, 'Gendering Mobility: Women, Work and Automobility in the United States' (2008) 93 History 376.

${ }^{101}$ David MacGregor, 'The Safety Race: Transititions to the Fourth Age of the Automobile' in J Conley and AT McLaren (eds), Car Troubles: Critical Studies of Automobility and Auto-Mobility (Ashgate, 2009).

${ }^{102}$ Ulrich Beck, Risk Society: Towards a New Modernity (London, Sage 1992).

${ }^{103}$ Anthony Giddens, 'Risk and Responsibility" (1999) 62 Modern Law Review 14; Wendy Chan and George S Rigakos, 'Risk, Crime and Gender' (2002) 42 British Journal of Criminology 743; Sandra Berns, 'Musing on the Legal Scene: Law, Populism and the Politics of Ressentiment' (2006) 25 Australian Feminist Law Journal 19.

${ }^{104}$ Brian Klein Season 13, Episode 7 Top Gear (BBC, Television, 2 August).

${ }^{105}$ Brian Klein Season 13, Episode 3 Top Gear (BBC, Television, 5 July). 
and the combustion in combustion masculinity faces extinction as electric motors and batteries replace the hydrocarbon snorting internal combustion engine. ${ }^{106}$ The images of risk-taking in cars within the show are obviously staged managed. Throughout season 13 there was little evidence of reckless driving on public roads - no suggestion of excessive speed, no street racing, and no evidence of a loss of traction or control of the car. Some liberties are taken, but they were trivial and for presentation's sake — such as a sweeping lane change without the use of an indicator. ${ }^{107}$ It was very obvious that Clarkson was not actually being subject to live fire as he attempted to evade the British Army in the Mitsubishi. ${ }^{108}$ In the racetrack scenes emergency vehicles and passive safety equipment (soft crash barriers, gravel speed traps, expanses of open turf before hard obstacles) were clearly visible. There was the illusion of risk, but the ultimate joke was that there was little risk; a charade of lawlessness partly obscuring highly managed, lawful activities.

This is the purpose of Top Gear. It is men laughing with, and at, men role-playing a past masculinity. It shows the silliness, the out-of-time-ness, the past-ness of combustion masculinity. A wet Hammond stands as the Vincent motorcycle undergoes emergency roadside repairs: 'It is however a very manly pursuit, I am enjoying it, testosterone surging round my system, or it could be actually rain - its getting in-yes its rain surging round my system., ${ }^{109}$ The Stig, the anonymous racing car driver renders combustion masculinity silly. The Stig is the best, fastest, most spectacular driver on the show. Yet his identity is not known. The whole visible economy of combustion masculinity falls with the Stig precisely because he is not seen. In laughing at combustion masculinity the show can be seen as progressive. It not only presents a gentle critique of combustion masculinity but also suggests ways of combining technology, gender and law that can overtake combustion masculinity.

In season 13, May won the most challenges. He won the challenges in episode 13:1, 13:5 and 13:6 and he wins through following the rules. Clarkson and Hammond duel and take risks and more often than not crash. May is even seen getting the girl in the rally challenge of 13:6, seemingly winning

\footnotetext{
${ }^{106}$ Urry (n 2) 33.

${ }^{107}$ Brian Klein Season 13, Episode 5 Top Gear (BBC, Television, 19 July).

${ }^{108}$ Brian Klein Season 13, Episode 4 Top Gear (BBC, Television, 12 July).

${ }^{109}$ Brian Klein Season 13, Episode 1 Top Gear (BBC, Television, 21 June).
} 
over his co-driver model Madison Welch. While Clarkson and Hammond are left homo-socialising with each other watching old cars do circuits of a racetrack, the final scene is May and Welch having a picnic under a tree. ${ }^{110}$ Quietly spoken and with a more thoughtful persona than the other two, May emerges from the post-ignition detritus of combustion masculinity as an alternative to combustion masculinity. Redshaw contrasts combustion masculinity with 'hydraulic masculinity." ${ }^{111}$ For her, hydraulic masculinity — taking its name from the strength and precision of construction machinery—is controlled, constructive and caring. ${ }^{112}$ While combustion masculinity destroys, hydraulic masculinity makes. It uses strength and precision to build and to maintain. Its focus is focus, not the onanistic male sexually climaxing through risk-taking in cars while watched by male onlookers, but a gifting to the world through doing. Its home lies in a primal sense of techné; a using of learnt skills to add to the beauty and complexity of the world. ${ }^{113}$ May's lawfulness, his risk aversion, his knowledge of automotive engineering, his distance from the excesses of combustion masculinity, presents him as much more appealing. He is not perfect. He swears when slow cars pulled in front of him $^{114}$ and he gets frustrated with Welch when they begin the rally. ${ }^{115} \mathrm{He}$ is still a lad—he still likes cars—just his engagement with automobility is more constructive. Indeed, once sensitive to hydraulic masculinity, this alternative is quite evident in Top Gear. It is there in the men in tweed hats at the pre-1980s car auction looking for vehicles to restore, ${ }^{116}$ and it shines through the grit and smoke on the faces of the men who remade and now are driving the steam train. ${ }^{117}$ This is caring, man-style. It might be caring about machines but it displays a responsibility to the world. It could also be seen in Clarkson and Hammond when they were not playing the fool. They talk, while May is having his victory picnic, about their joy of being around 'car people' at the car rally; that is around men who restore and care for old cars; and all three indicate that they purchased from the BBC their cars from that challenge to

\footnotetext{
${ }^{110}$ Brian Klein Season 13, Episode 6 Top Gear (BBC, Television, 26 July).

${ }^{111}$ Redshaw (n 33) 100 and 164.

${ }^{112}$ Ibid, 163-164.

${ }^{113}$ Martin Heidegger, 'The Question Concerning Technology'The Question Concerning Technology and Other Essays (Harper and Row, 1977). On the masculinity of Heidegger's account of technology see Steve Garlick, 'What is a Man?: Heterosexuality and the Technology of Masculinity' (2003) 6 Men and Masculinity 156, 160-2.

${ }^{114}$ Brian Klein Season 13, Episode 1 Top Gear (BBC, Television, 21 June).

${ }^{115}$ Brian Klein Season 13, Episode 6 Top Gear (BBC, Television, 26 July).

${ }^{116}$ Ibid.

${ }^{117}$ Brian Klein Season 13, Episode 1 Top Gear (BBC, Television, 21 June).
} 
restore. ${ }^{118}$ Hydraulic masculinity is not without its concerns. Its manifestation as machine maintenance in Top Gear is mostly irrelevant to the semi-intelligent, disposable, white-good on wheels that is the contemporary automobile. In that hydraulic masculinity industrial-ness is as out-oftime in the post-industrial West as is combustion masculinity. Further Ulf Mellsröm has concerns that the sort of technical knowledge - 'rituals of tinkering' - that lies behind car care can be seen as a site for male technological knowledge/power that excludes women. ${ }^{119}$ Both critiques are valid for this expression of masculinity. However, focusing on the negatives of expression inhibits assessment of what can be seen as positive within hydraulic masculinity. Rather than its manifestation through tinkering with cars, the drive behind this tinkering can be emphasised. While hydraulic masculinity is not without its criticisms, in its emphasis on making and care — on responsibility to the world—-there is a chassis onto which men can be constructive without the violence and destruction of combustion masculinity.

Like combustion masculinity, hydraulic masculinity has its constitution within legality. Whereas in combustion masculinity law provided the transgressive benchmark, hydraulic masculinity's making and care means working with law and a sensible orientation towards risk. Law goes from a negative constraint against which masculinity is defined to a set of resources through which sustainable and permanent making can happen. Law can be seen as a guide to doing well in the world. In addition, risk becomes removed from male identity. Identity shifts to pride in what has been made or what has been cared for. Risk becomes considered in more 'risk society' terms as unnecessary and corrosive to sustained doing-in-the-world. So while the expression of hydraulic masculinity in Top Gear in car maintenance and restoration is as much a dinosaur as combustion masculinity, the constituent elements of hydraulic masculinity—care, making, responsibility—have a future. Like the animatronic dinosaurs that bizarrely accompanied the review of the BMW Z4 in $13: 6^{120}$, hydraulic masculinity might look old but it is what is inside that makes it new. Hydraulic masculinity, and ultimately Top Gear shows, that men can see the silly, unnecessary danger of combustion masculinity, and they can

\footnotetext{
${ }^{118}$ Brian Klein Season 13, Episode 6 Top Gear (BBC, Television, 26 July).

${ }^{119}$ Ulf MellsrÖm, 'Machines and Masculine Subjectivity: Technology as an Integral Part of Men's Life Experiences' (2004) 6 Men and Masculinity 368, 380.

${ }^{120}$ Brian Klein Season 13, Episode 6 Top Gear (BBC, Television, 26 July).
} 
still be men, yet build and care in the world. What the show performs are two messages. First, that traditional masculine values, risk and violence, are out of time; and second, that there can be more lawful, constructive and caring ways of being male through and in law.

\section{CONCLUSION}

This paper undertook a cultural legal study of Top Gear. It showed that the excessive performance of combustion masculinity by Top Gear revealed not only the essential elements of combustion masculinity in risk-taking and the visual but the significance of law as the measure of risk and therefore the legality of combustion masculinity. Taking the irony that the transgressive orientation of combustion masculinity was necessarily lawful, the study continued to examine the humour and irony in the show. The heterosexuality of combustion masculinity was seen as transposed by a queer subtext and the humour of the show was directed at combustion masculinity. In linking combustion masculinity to the car and then emphasising the decline of the car in the post-industrial era, Top Gear appears a gentle critique of combustion masculinity. The study concludes by showing that Top Gear not only allows a letting go of combustion masculinity with laughter and humour, but also less risky, less violent and more lawful ways of being male in the present through emphasis on making, care and responsibility. 